\title{
Effect of dietary fishmeal replacement in the formulated food by heat processed soybean meal on growth, survival and crude protein level of fingerlings of Genetically Improved Farm Tilapia (GIFT)
}

\author{
M.D.M.D.W.M.M.K.Y A T A W ARÄAND M. HETTIARACHCHI \\ Department of Zoology, University of Kelaniya, Kelaniya, Sri Lanka. \\ *Corresponding author (Present address: National Institute of Fisheries and \\ Nautical Engineering, Crow Island, Colombo 15, Sri Lanka. E-mail: \\ mmkyat@yahoo.com)
}

\begin{abstract}
A feeding trial was conducted to evaluate the effect of dietary fishmeal replacement in the formulated food by heat processed soybean meal on growth, survival and crude protein level of fingerlings of Genetically Improved Farm Tilapia (GIFT) Six experimental diets were formulated to be isonitrogenous approximately. The diet 1 (control diet) contained $100 \%$ fishmeal and $0 \%$ soybean meal. Fishmeal was partially replaced by $10 \%$, $25 \%, 30 \%, 40 \%$ and $50 \%$ of heat-treated soybean meal in the diets 2 to 6 . Early GIFT fingerlings (body weight $1.92 \pm 0.10 \mathrm{~g}$ ) were reared in $164 \mathrm{~L}$ indoor fiberglass tanks and 3 replicates were arranged for each experimental diet. Each tank was provided with continuous mild aeration. Feed ration was $10 \%$ of total fish biomass over the first 30 days which was divided and offered at 09:00 h, 12:00 $\mathrm{h}$ and 16:00 $\mathrm{h}$ daily and the amount was reduced up to $8 \%$ of total fish biomass for the next 30 days. Results showed that percentage weight gain recorded in fish fed with the experimental diets 4,5 and 6 (where fish meal was replaced by $30 \%, 40 \%$ and $50 \%$ soybean meal respectively) were not significantly different from that of fish fed with the control diet $(\mathrm{P}<0.05)$. There was no significant difference in specific growth rate of fish fed with the control diet and any of the experimental diets $(\mathrm{P}<0.05)$. Survival of the fish fed with the control diet and the fish that received the diet 5 was $100 \%$ at the end of 60 days study period. The lowest feed conversion ratios were recorded for the control diet (1.44) and for the experimental diet 5 (1.49). The fish fed with the diet 5 had the highest percentage of crude protein $(59.35 \%)$, which was significantly higher $(\mathrm{P}<0.05)$ than that of the fish fed with diet 1 (control diet), 2 and 4 . Cost of producing $1 \mathrm{~kg}$ of feed also was considerably low for the diet 5 compared to the control diet. The results show that $40 \%$ of fishmeal in a formulated diet for early fingerlings could be replaced by heat processed soybean meal with
\end{abstract}


no adverse effects on growth, survival, FCR and crude protein level of young GIF tilapia at the end of 60 days of experimental period.

\section{Introduction}

Tilapias are widely cultured in the tropical and sub tropical regions of the world and constitute the third largest group of farmed finfish only after carps and salmonids. Oreochromis niloticus was promoted for genetic research due to its growing importance in tropical and sub tropical aquaculture, relatively short generation time of about 6-8 months, the utility in investigating the application of genetics on the species in aquaculture, having many desirable traits, comparatively high resistance to pathogenic and parasitic diseases and suitability in culture in a wide range of farming systems (Eknath et al. 1996). The culture performance of the selectively bred strain, Genetically Improved Farm Tilapia (GIFT) was much better compared to the non-GIFT strain of $O$. niloticus in terms of growth in both pond and cage culture systems (Dey et al. 2000).

The development of commercial aqua feeds has been traditionally based on fishmeal as the main protein source due to its high protein content and balanced amino acid profile (Fattah \& El-Sayed 1999). Fishmeal has been the most expensive one among the ingredients used for feed formulation. The shortage in global fishmeal production coupled with increased demand and competition for its use in livestock and poultry feeds has further increased fishmeal prices. Storebakken et al. (2000) pointed out that soybean meals are widely used as the most cost-effective alternative for fishmeal in feeds formulated for many fish species employed in aquaculture. GIF tilapia was introduced to Sri Lanka in 2001. It is cultured by private sector entrepreneurs and the production is mainly sold for tourist hotels. These fish are fed with commercially available formulated feeds with different levels of protein. In the present study, the effect of dietary fish meal replacement by heat processed soybean meal on growth, survival and crude protein level of GIF tilapia was evaluated with a view to find out the most suitable composition of fish meal : soybean meal in a formulated food prepared for young GIF tilapia.

\section{Materials and Methods}

\section{Experimental diets and diet preparation}

The composition of the 6 experimental diets is shown in Table1. Dietary protein level of the control diet (diet 1) was estimated as $35.8 \%$ which is the recommended level of protein for fry of tilapias (Hertrampf and Pascual, 2000) supplied with only fishmeal without adding soybean meal (SB). From diet 2 to diet 6 heat processed soybean meal was incorporated 
replacing fishmeal at increasing percentage replacement $(0-50 \%)$ on an approximately isonitrogenous basis.

Six types of dietary treatments were as follows: Diet $1,100 \%$ fish meal with $0 \% \mathrm{SB}$; diet $2,90 \%$ fish meal with $10 \% \mathrm{SB}$; diet 3, 75\% fish meal with $25 \% \mathrm{SB}$; diet $4,70 \%$ fish meal with $30 \% \mathrm{SB}$; diet 5, 60\% fish meal with $40 \% \mathrm{SB}$; diet $6,50 \%$ fish meal with $50 \% \mathrm{SB}$. Other dietary components were vegetable oil $(6 \%)$, wheat flour as binder, vitamin and mineral premixes, and rice bran mainly as the filler. All dietary ingredients were obtained commercially. Experimental diets were prepared in the laboratory using the standard procedure described by Millamena (2002).

Table 1. Ingredients used for the experimental diets as $\mathrm{g} 100 \mathrm{~g}$ dry matter

\begin{tabular}{lclllll}
\hline Ingredients & Diet 1 & Diet 2 & Diet 3 & Diet 4 & Diet 5 & Diet 6 \\
& $0 \%$ & $10 \%$ & $25 \%$ & $30 \%$ & $40 \%$ & $50 \%$ \\
& SB & SB & SB & SB & SB & SB \\
\hline Fish meal & 40 & 36 & 30 & 28 & 24 & 20 \\
Soybean meal & 0 & 5 & 12.5 & 15 & 20 & 25 \\
Wheat flour & 32 & 32 & 32 & 32 & 32 & 32 \\
Rice bran & 17 & 16 & 14.5 & 14 & 13 & 12 \\
Vitamin & 2 & 2 & 2 & 2 & 2 & 2 \\
Mineral premix & 3 & 3 & 3 & 3 & 3 & 3 \\
Vegetable oil & 6 & 6 & 6 & 6 & 6 & 6 \\
\hline
\end{tabular}

SB- Soybean meal

\section{Experimental fish}

Early fingerlings of Genetically Improved Farm Tilapia (GIFT; body weight ranging from 1.59 to $2.00 \mathrm{~g}$ ) were obtained from the Udawalawa fish breeding station, National aquaculture Development Authority of Sri Lanka. They were transported to the laboratory and acclimated in fiberglass tanks (164 L) for a week. During acclimation, fish were fed with a commercially available feed.

\section{Feeding experiments}

Fish with mean initial body weight of $1.92 \pm 0.10 \mathrm{~g}$ were sorted and 15 fish were allotted to clean indoor fiberglass tanks with aged aerated water. The volume of water in each fiberglass tank was $164 \mathrm{~L}$ and three replicates were arranged for each diet; each tank was provided with mild aeration.

Feed ration was $10 \%$ of the total fish biomass per day over the first 30 days, which was divided and offered at 09:00h, 12:00h and 16:00h. Feces were siphoned out daily and daily mortality (if present) was recorded. Fifty percent of rearing water was drained and replaced with aged aerated tap water twice a week. After the first 30 days fish were bulk weighed and daily feeding ration was reduced to $8 \%$ of total fish biomass and offered as before. Feeding experiment was carried out for 60 days. 
Parameters used to determine diet performance were growth expressed as percentage weight gain and specific growth rate (SGR), survival and feed conversion ratio (FCR) and body crude protein level of fingerlings. These parameters were determined at the termination of the 60 day culture period. The total cost to prepare $1 \mathrm{~kg}$ of each diet was also calculated considering the prices of ingredients.

\section{Chemical analysis and water quality parameters}

Methodologies presented in AOAC (2000) were used to analyze proximate composition of experimental diets and crude protein level of GIFT fingerlings fed with each diet. Temperature, $\mathrm{pH}$ and Dissolved oxygen concentration of water were recorded using $\mathrm{HACH}$ water quality monitors (HACH Company, Colorado, USA). Concentrations of ammonia nitrogen and nitrite nitrogen in water were estimated according to the methods given by Patnaik (1997) and APHA (1998) respectively.

\section{Statistical analysis}

Results were statistically analyzed using one-way analysis of variance (ANOV A) followed by Tukey's pairwise comparisonto compare the means at 5\% level of significance. The software, Minitab Version 13.3 was used in the statistical analysis.

\section{Results}

\section{Proximate analysis of experimental diets}

The composition of major nutrients of the diets prepared was more or less similar (Table 2) and fell within a narrow range (protein 28.8 - 31.04\%; crude fat $7.93-9.38 \%$; moisture $8.25-10.20 \%$; ash $7.94-9.90 \%$ and crude fiber $7.73-9.72 \%$ ).

Table 2. The proximate composition of the experimental diets (\% values on dry weight basis)

\begin{tabular}{lcccccc}
\hline $\begin{array}{l}\text { Experimental } \\
\text { diet }\end{array}$ & $\begin{array}{l}\text { Crude } \\
\text { fat }\end{array}$ & $\begin{array}{l}\text { Crude } \\
\text { protein }\end{array}$ & Moisture & Ash & $\begin{array}{l}\text { Crude } \\
\text { fiber }\end{array}$ & $\begin{array}{l}\text { N-free } \\
\text { extract }\end{array}$ \\
\hline $1(0 \% \mathrm{SB})$ & 7.93 & 31.04 & 8.25 & 9.56 & 7.45 & 29.77 \\
$2(10 \% \mathrm{SB})$ & 9.38 & 29.95 & 9.95 & 9.20 & 8.04 & 33.48 \\
$3(25 \% \mathrm{SB})$ & 8.52 & 30.53 & 8.90 & 9.90 & 7.73 & 34.42 \\
$4(30 \% \mathrm{SB})$ & 7.96 & 30.65 & 10.20 & 8.91 & 9.72 & 32.56 \\
$5(40 \% \mathrm{SB})$ & 8.43 & 28.80 & 9.43 & 7.94 & 9.25 & 36.15 \\
$6(50 \% \mathrm{SB})$ & 8.27 & 30.42 & 9.36 & 8.98 & 8.93 & 34.04 \\
\hline
\end{tabular}

SB-Soybean meal 


\section{Growth, survival and feed conversion efficiency}

Table 3 summarizes the mean values of percentage weight gain, specific growth rate, survival and feed conversion ratios of fingerlings of young GIFT fed with different experimental diets. Just after the transportation, fish did not accept the food though the water quality parameters were within the acceptable range and fish appeared to be healthy. It was observed that fingerlings of GIFT gradually adapted to accept the formulated food provided during the present study.

At the end of the study period, percentage weight gain achieved by young fish varied between $360 \%$ to $490 \%$. Percentage weight gain recorded for the fish fed with diet 2 and 3 were significantly lower $(\mathrm{P}<0.05)$ than that of the control diet (diet 1), while the percentage weight gain recorded for fish fed with diet 4, 5 and 6 did not show a significant difference from that of the fish fed with the control diet ( $\mathrm{P}>0.05$; Table 3 ). Specific growth rate ranged from 2.58 to 2.86 and the differences recorded in SGR of tilapia fed with different experimental diets were not statistically significant $(\mathrm{P}>0.05)$.

Mean percentage survival of young tilapia fed with different experimental diets did not show a significant difference $(\mathrm{P}>0.05)$ and varied between $91 \%$ and $100 \%$ by the end of the study period. Fish fed with experimental diet 1 and diet 5 had 100\% survival. The lowest mean FCR was recorded for the fish fed with experimental diet $1(1.44 \pm 0.05)$ while the highest was recorded for the group fed with diet $2(1.76 \pm 0.12)$. However, there was no significant difference between the mean FCR of fish recorded for the control diet and those recorded for other experimental diets (Table 3).

The mean body crude protein percentage of young GIFT fed with experimental diet 5 and 6 were significantly higher $(\mathrm{P}<0.05)$ than those of the fish fed with diets1, 2 and 4 (Table 4). The total cost to prepare $1 \mathrm{~kg}$ of diet varied from Rs. 65.05 to Rs.48.80.

During the present study, water temperature in culture tanks varied between $26.3^{\circ} \mathrm{C}$ and $28.1^{\circ} \mathrm{C}$ while dissolved oxygen content ranged from 4.44 $\mathrm{mg}^{-1}$ to $4.89 \mathrm{mg}^{-1}$. Water $\mathrm{pH}$ fluctuated between 6.7 and 7.1 while ammonia nitrogen and nitrite nitrogen varied between $0.09 \mathrm{mg} \mathrm{I}$ and 0.13 $\mathrm{mg} 1^{-1}$ and $0.002 \mathrm{mg}^{-1}$ and $0.010 \mathrm{mg}^{-1}$ respectively. There was no significant difference in any of the water quality parameters in different tanks in relation to the differences in these tested diets (Table 5). 
Table 3. Growth performance of young Genetically Improved Farm Tilapia fed with experimental diets containing variable amounts of soybean meal (SB)

\begin{tabular}{lllllcc}
\hline Parameter & $\begin{array}{l}\text { Diet1 } \\
(0 \% \mathrm{SB})\end{array}$ & $\begin{array}{l}\text { Diet } 2 \\
(10 \% \mathrm{SB})\end{array}$ & $\begin{array}{l}\text { Diet 3 } \\
(25 \% \mathrm{SB})\end{array}$ & $\begin{array}{l}\text { Diet } 4 \\
(30 \% \mathrm{SB})\end{array}$ & $\begin{array}{l}\text { Diet 5 } \\
(40 \% \mathrm{SB})\end{array}$ & $\begin{array}{l}\text { Diet 6 } \\
(50 \% \mathrm{SB})\end{array}$ \\
\hline Initial body weight $(\mathrm{g})$ & $2.10^{\mathrm{a}} \pm 0.10$ & $2.17^{\mathrm{a}} \pm 0.09$ & $2.02^{\mathrm{a}} \pm 0.06$ & $1.96^{\mathrm{a}} \pm 0.01$ & $1.84^{\mathrm{a}} \pm 0.03$ & $1.82^{\mathrm{a}} \pm 0.12$ \\
Final body weight $(\mathrm{g})$ & $12.4^{\mathrm{a}} \pm 0.70$ & $10.73^{\mathrm{a}} \pm 0.37$ & $9.83^{\mathrm{b}} \pm 0.37$ & $9.68^{\mathrm{b}} \pm 0.10$ & $10.42^{\mathrm{b}} \pm 0.29$ & $9.69^{\mathrm{b}} \pm 0.12$ \\
\% weight gain & $490^{\mathrm{a}} \pm 7.34$ & $360^{\mathrm{b}} \pm 8.25$ & $380^{\mathrm{b}} \pm 7.38$ & $417^{\mathrm{ab}} \pm 7.51$ & $466^{\mathrm{ab}} \pm 8.12$ & $440^{\mathrm{ab}} \pm 9.51$ \\
SGR $\left(\%\right.$ day $\left.{ }^{-1}\right)$ & $2.86^{\mathrm{a}} \pm 0.14$ & $2.64^{\mathrm{a}} \pm 0.06$ & $2.63^{\mathrm{a}} \pm 0.08$ & $2.58^{\mathrm{a}} \pm 0.14$ & $2.76^{\mathrm{a}} \pm 0.17$ & $2.74^{\mathrm{a}} \pm 0.10$ \\
FCR & $1.44^{\mathrm{a}} \pm 0.05$ & $1.76^{\mathrm{a}} \pm 0.12$ & $1.66^{\mathrm{a}} \pm 0.05$ & $1.66^{\mathrm{a}} \pm 0.02$ & $1.49^{\mathrm{a}} \pm 0.04$ & $1.58^{\mathrm{a}} \pm 0.03$ \\
\% survival & $100^{\mathrm{a}}$ & $91^{\mathrm{a}} \pm 3.61$ & $95.5^{\mathrm{a}} \pm 1.82$ & $95.5^{\mathrm{a}} \pm 1.82$ & $100^{\mathrm{a}}$ & $95.5^{\mathrm{a}} \pm 1.82$ \\
\hline
\end{tabular}

Values are presented as means \pm S.E., Means in each row with different superscripts are significantly different from each other (ANOV A, Tukey's test, $\mathrm{P}<0.05$ ). 
Table 4. The crude protein percentages of young Genetically Improved Farm Tilapia fed with different diets and the total cost to prepare $1 \mathrm{~kg}$ of each experimental diet considering the prices of ingredients.

\begin{tabular}{lllllll}
\hline & \multicolumn{5}{c}{ Diet } \\
& 1 & 2 & 3 & 4 & 5 & 6 \\
\hline $\begin{array}{l}\text { Crude protein } \\
\text { \% as dry basis }\end{array}$ & $53.75^{\mathrm{a}}$ & $52.95^{\mathrm{a}}$ & $54.95^{\mathrm{b}}$ & $53.70^{\mathrm{a}}$ & $59.35^{\mathrm{bc}}$ & $59.00^{\mathrm{bc}}$ \\
$\begin{array}{l}\text { (Mean } \pm \text { S.E.) } \\
\text { Mean }\end{array}$ & & & & & & \\
Total cost & 65.05 & 61.80 & 56.92 & 55.30 & 52.05 & 48.80 \\
(Rs.) & & & & & & \\
\hline
\end{tabular}

Values are presented as means \pm S.E., Means in each row with different superscripts are significantly different from each other (ANOV A, Tukey's test, $\mathrm{P}<0.05)$.

Table 5. Water quality parameters in the different fiberglass tanks containing GIF tilapia which received different experimental diets

\begin{tabular}{lllllll}
\hline Parameter & Diet 1 & Diet 2 & Diet 3 & Diet 4 & Diet 5 & Diet 6 \\
\hline DO $\left(\mathrm{mg} \mathrm{L}^{-1}\right)$ & 4.52 & 4.76 & 4.46 & 4.44 & 4.89 & 4.85 \\
& \pm 0.07 & \pm 0.16 & \pm 0.15 & \pm 0.08 & \pm 0.11 & \pm 0.08 \\
Temperature $\left({ }^{0} \mathrm{C}\right)$ & 28.0 & 26.4 & 26.3 & 28.1 & 27.3 & 27.2 \\
& \pm 0.13 & \pm 0.09 & \pm 0.08 & \pm 0.15 & \pm 0.13 & \pm 0.14 \\
$\mathrm{pH}$ & 7.0 & 6.7 & 6.7 & 7.0 & 7.1 & 7.0 \\
& \pm 0.05 & \pm 0.08 & \pm 0.07 & \pm 0.05 & \pm 0.06 & \pm 0.03 \\
$\mathrm{NH}_{3}-\mathrm{N}\left(\mathrm{mg} \mathrm{L}^{-1}\right)$ & 0.11 & 0.09 & 0.09 & 0.12 & 0.13 & 0.10 \\
& \pm 0.05 & \pm 0.03 & \pm 0.04 & \pm 0.06 & \pm 0.01 & \pm 0.03 \\
$\mathrm{NO}_{2}-\mathrm{N}\left(\mathrm{mg} \mathrm{L}^{-1}\right)$ & 0.008 & 0.002 & 0.005 & 0.009 & 0.010 & 0.008 \\
& \pm 0.002 & \pm 0.003 & \pm 0.003 & \pm 0.002 & \pm 0.002 & \pm 0.003 \\
\hline
\end{tabular}

Values are presented as means \pm S.E. Means in each row, were not significantly different from each other (ANOV A, P >0.05).

\section{Discussion}

In intensive aquaculture, fish feeding represents over $50 \%$ of operating costs and protein is the most expensive dietary source. Fishmeal is an excellent source of essential fatty acids, essential amino acids, digestible energy, minerals and vitamins (Fattah \& El-Sayed, 1999). However, as the 
demand for fishmeal and marine fishery products for aquaculture increases and the availability decreases cost of fishmeal is expected to rise. Therefore, a dependable supply of cost-effective source of protein preferably a plant based one must be employed for fish farming to be profitable. According to ElSayed \& Teshima (1992), juvenile tilapia with appropriate body weight ranging from 0.5 to $5 \mathrm{~g}$ need protein levels of $29 \%$ to $40 \%$ in the diet to achieve maximum growth. For the present study, GIFT fingerlings with body weight $1.92 \pm 0.10 \mathrm{~g}$ were used and the diet prepared as the control (diet 1) with fishmeal as the only protein source had $31.04 \%$ protein.

Soybean meal is the best plant protein source in terms of protein content and essential amino acid profile (Fattah and El-Sayed 1999) and fishmeal was replaced by the soybean meal at different percentages during the present study. It was observed that percentage weight gain recorded for diet 2 and 3 was significantly lower than that was recorded for diet 1; it would be interesting to carry out a further study to investigate the exact reason for this observation. The percentage weight gains recorded for young fish fed with experimental diet 4, 5 and 6 (where $30 \%, 40 \%$ and $50 \%$ fish meal were replaced with soybean meal) were not significantly different from that of fish fed with the control diet indicating that the replacement of fish meal by soybean meal at these levels has not had an effect on the growth performance of young GIFT. The mean specific growth rate recorded for diet 5 is much closer to that of diet 1 (control diet) confirming that the replacement of $40 \%$ fishmeal by soybean meal is accepted well by young GIFT.

According to Davis and Stickney (1978), the inclusion level of soybean meal in tilapia feeds is affected by dietary protein level. The inclusion of soybean meal at $15 \%$ dietary protein impaired the growth of blue tilapia, while at $36 \%$ protein; soybean meal could totally replace the fishmeal in the diets without significant reduction in the performance of fish. However, contradictory results have been reported by Shiauet al (1989); these authors found out that at $24 \%$ dietary protein level, $67 \%$ of fish meal could be replaced with soybean meal, while at $32 \%$ protein level, replacement of $30 \%$ fish meal with soybean meal significantly decreased the growth of fish and feed efficiency. This could be due to poor amino acid balance and the presence of trypsin inhibitor in soybean meal (Shiauet al. 1987).

Several studies also have reported reduced growth at higher levels of soybean meal inclusion in fish diets (Dabrowski and Kozak 1979). However, Balogun and Ologhobo (1989) pointed out that the cooked soybean dietary inclusion was superior. During the present study heat treated soybean meal was incorporated to replace fish meal in formulated experimental diets and at $35.8 \%$ dietary protein level $30 \%, 40 \%$ and $50 \%$ fish meal could be replaced by soybean meal without having a significant effect on growth performance of young GIFT. Interestingly percentage weight gains recorded for the diet 2 and 3 , where $10 \%$ and $25 \%$ fishmeal were replaced with soybean meal, were significantly lower than that of the control diet. 
Webster and Lim (2002) stated that tilapia accept a variety of diets in meal form and in moist, sinking and floating pellets. All experimental diets prepared during the present study sank to the bottom of the tank and young tilapias were observed to feed on them comfortably. In the present study, mortality of fish was observed only within the first two weeks in some experimental tanks. This may be attributed to the stress due to handling. There were no mortality in any of the tanks after two weeks. At the end of 60 days experimental period percentage survival recorded for young GIFT was over $91 \%$ for all experimental diets indicating the ability of the tilapia to adapt quickly to different diets. However, $100 \%$ survival was recorded for the fish fed with the control diet and with the diet 5, where $40 \%$ fishmeal was replaced with soybean meal.

Food conversion ratio (FCR) of experimental diets varied between 1.44 (diet 1 with $0 \% \mathrm{SB}$ ) and 1.76 (diet 2 with $10 \% \mathrm{SB}$ ) while FCR of diet 1 and 5(1.49; where $40 \%$ fish meal was replaced with SB) were closer to one another compared to the FCR recorded for other experimental diets (Table 3 ). Though there was no significant difference, FCR recorded for experimental diet 5 was low. The lower FCR and increased percentage weight gain recorded for experimental diets 5 ( $40 \%$ fish meal is replaced with SB) could lower the production cost.

The mean crude protein percentages of young GIFT fed with experimental diets $5(59.35)$ and diet $6(59.00)$ were significantly higher than that of diet 1 (53.75). Although the crude protein percentage was higher in the control diet, the assimilation of body protein appears to be low indicating that the efficiency of assimilation of protein is reduced when the diet provided for young GIFT contains $100 \%$ fishmeal as the protein source. It would be interesting to study the protein assimilation ability of GIFT under different protein levels and by incorporating different protein sources for the formulated diets for this fish.

When percentage weight gain, \% survival and body protein level of young GIFT recorded during the study are considered it could be concluded that soybean meal was most efficiently utilized when $40 \%$ fish meal is replaced with it. However, further studies are required to determine the performance of GIFT juveniles up to marketable size when fed with the fishmeal replacement diets at on-farm conditions.

\section{Acknowledgement}

The ADB Science and Technology Personnel Development Project, Sri Lanka is acknowledged for funding the first author to follow the Master degree programme in Aquaculture and Fisheries Management at the Department of Zoology, University of Kelaniya, Sri Lanka. 


\section{References}

AOAC, 2000.

Association of Official Analytical Chemists, Official Methods of Analysis of AOAC INTERNA TIONAL, Vol. 1. Gaithersburg, USA, $769 \mathrm{p}$.

APHA, 1998.

Standard Methods for the Examination of Water and Wastewater, American Public Health Association, Washinngton DC, $1092 p$.

Balogun, A.M \& A.D. Ologhobo 1989.

Growth performance and nutrient utilizationof fingerlingClarias gariepinus (Burchell) fed raw and cooked soybean diets. Aquaculture 76: 119-126.

Dabrowski, K. \& B. Kozak 1979.

The use of fish meal and soyabean meal as a protein source in the diet of grass carp fry. Aquaculture 18: 107-114.

Davis, A.T.\& R.R Stickney 1978.

Growth responses of Tilapia aurea to dietery protein quality and quantity. Transactions of the American Fisheries Society 107: 479483.

Dey, M.M., A.E. Eknath, L.I. Sifa, M.G. Hussain, T.M. Thien, N.V . Hao, S.

Aypa, \& N. Pongthana 2000.

Performance and nature of genetically improved farmed tilapia: A bioeconomic analysis. Aquaculture Economics And Management 4 (1\& 2): 85-108.

Eknath, A.E., J.B. Capili, M.S. Danting, E.E Palada de vera, H.L Dionisio, R.A. Bolivar, Reyes \& M.M Tayamen 1996.

A practical quantitative method to estimate relative reproductive activity in Oreochromis niloticus, In: The third International Symposium on Tilapia in Aquaculture. R.S.V . Pullin, J. Lazard, M. Legendre, J.B. Amon Kothias \& D. Pauly eds.) pp 290-298, ICLARM conference Procedings 41, 350p , ICLARM, Manila.

El-Sayed, A.F.M. \& S.I. Teshima 1992.

Protein and energy requirements of Nile tilapia, Oreochromis niloticus fry. Aquaculture 103: 55-63.

Fattah, A.\& M. El-Sayed 1999.

Alternative dietary protein sources for farmed tilapia,Oreochromis spp. Aquaculture179: 149-168.

Hertrampf, J.W . \& F.P Pascual 2000.

Handbook on Ingredients for Aquaculture Feeds. Kluwer Academic Publishers, Dordrecht, The Netherlands 573p.

Millamena, O.M. 2002.

Replacement of fish meal by animal by product meals in a practical diet for grow-out culture of grouper Epinephelus coioides. Aquaculture 204: 75-84. 
.Patnaik, P. 1997.

Hand Book of Environmental Analysis: Chemical pollutants in air, water, soil and solid wastes/ P.P.Lewis Publishers, Boca Raton, Florida 583p.

Shiau, S.Y ., J.L. Chuang, \& C.L. Sun 1987.

Inclusion of soybean meal in tilapia (Oreochromis niloticus x $O$. aureus) diets at two protein levels. Aquaculture 65 (3-4): 251-261.

Shiau, S.Y ., C.C. Kwok, J.Y. Hwang, C.M. Chen, \& S.L. Lee 1989. Replacement of fishmeal with soybean meal in male tilapia (Oreochromis niloticus $\mathrm{x} O$. aureus) fingerling diets at a suboptimal level. Journal of the W orld Aquaculture Society 20(4): 230-235

Storebakken, T., S. Refstie \& B. Ruyter 2000.

Soy products as fat and protein sources in fish feeds for intensive aquaculture. In: Soy in Animal Nutrition. Drackley, J.K. (Ed.), Federation of Animal Science Societies, Savoy, IL, USA, 127-170.

Webster, C.D. \& C.E. Lim, 2002.

Nutrient requirements and feeding of finfish for aquaculture. CABI Publishing, Wallingford, UK 418p. 
